\title{
PERCEPTIONS ABOUT MARINE ENVIRONMENTAL ISSUES BY CITIZENS WHO ARE MOSTLY FROM MINAS GERAIS STATE (BRAZIL)
}

\author{
Fellipe Dias Tavares de Simas ${ }^{1}$ \\ Eugênio Batista Leite ${ }^{2}$
}

\begin{abstract}
Despite the marine ecosystems' importance, the anthropogenic actions have been impacting these environments negatively. However, these impacts could be mitigated through Environmental Education (EE), which is able to change behaviors that are harmful to the environment. This study aimed to describe environmental perception of the majority population in Minas Gerais state, in order to provide subsidies for marine environmental education's promotion. The methodology adopted was through questionnaire's application via Google forms. The studied subjects totaled 122 people over 18 years old, although they had conceptual domain, they showed an utilitarian tendency about marine resources.
\end{abstract}

Keywords: Environmental Education; Marine Biology; Conservation; Ocean; Preservation.

Resumo: Apesar de toda a importância dos ecossistemas marinhos, eles vêm sendo impactados negativamente. A Educação Ambiental (EA) marinha, embora escassa no país, é capaz de mudar esse quadro. O presente estudo objetivou descrever a percepção ambiental da população de maioria do estado de Minas Gerais, com a finalidade de fornecer subsídios para a promoção da EA marinha. A metodologia adotada foi a aplicação de um questionário via Google forms. Os sujeitos estudados perfizeram 122 pessoas maiores de 18 anos e embora tenham apresentado domínio conceitual, evidenciaram forte tendência utilitarista dos bens naturais marinhos.

Palavras-chave: Educação Ambiental; Biologia Marinha; Conservação; Oceano; Preservação.

1 Pontifícia Universidade Católica de Minas Gerais. E-mail: simas.fellipe@gmail.com 2 Pontifícia Universidade Católica de Minas Gerais. E-mail: eugeniobl@pucminas.br 


\section{Introduction}

Marine environment constitutes approximately $70 \%$ of all earth surface, and besides being interconnected, the oceans are divided in four big basins: Pacific Ocean, which is the deepest and biggest one; Atlantic, which bathes Brazilian coast; Indian Ocean and the Arctic Ocean, which is the smaller and shallowest among the others (CASTRO; HUBER, 2012).

It is important to highlight that many species of animals and plants discovered until now belong to the marine environment, which shows that the oceans shelter a wide biodiversity. (FELíCIO et al., 2012). In addition to being home of a wide range of species, they also provide life support on Earth, due to the fact that the oceans are responsible for absorbing the carbon dioxide in the atmosphere, mitigating the impacts caused by the greenhouse effect, in addition, ocean waters after evaporating are responsible to replace other water bodies by precipitation (CASTRO; GRASSI, 2001; HUBER, 2012; CAMPOS; JARDIM, 2003). Furthermore, the seas have always been of extreme economic and cultural importance for the mankind, being responsible for several activities, such as: Fishing, tourism, leisure, transport and not least important, food resources (BARROS-PLATIAU et al., 2015). The marine resources are also a big ally when it comes to human health, since several scientific research in the pharmaceutical field using marine resources enable the development of drugs that can be used on treating numerous diseases. (FELÍCIO et al., 2012). It is also noticeable that many economic activities related to the oceans provides jobs every year what consequently develops the economy (SOUZA et al., 2010).

Although even knowing marine environment's importance, the oceans are still suffering numerous impacts caused by anthropogenic actions. Such impacts like pollution by dumping or marine overexploitation can bring consequences to marine resources, cause irreversible damage to marine populations, disturb fishing activities, and even cause problems to human health (GODOI et al., 2003). Marine littering can also affect these environments' aesthetics. In addition, this can cause economic issues considering that littering would directly affect touristic areas (CALDAS, 2007).

It is important to highlight that the United Nations (UN), proposed in 2020 the Ocean Decade. The Ocean Decade aims not only making clear for public the oceans' importance, but also to stimulate actions from public and private spheres, thus aiming to implement actions for oceans' sustainability and to value the ecosystem services provided by them (UNESCO, 2020). These goals are very similar to those proposed by Environmental Education (EE), which is an important tool when it comes to terrestrial and marine environments' conservation. Environmental Education aims to modifying consumerist habits and any other that may disturb de environment (PEDRINI et al., 2010). According to National Environmental Education Policy - Law no 9795 of 1999, Article 1, Environmental Education can be defined as: 
Processes which the individual and the community build social values, knowledges, skills, attitudes and competences aimed to the environment's conservation, a common good for the people, essential to a healthy life's quality and its sustainability.

Furthermore, for EE activities to achieve their goals, it is essential that they are based on well-defined and previously tested models (BERCHEZ et al., 2007). Among these methods, we have the environmental perception. Environmental perception can be defined as the way that the man sees the environment according to his knowledge, culture, experiences, and emotions (SILVA et al., 2002). Within this environmental perspective, it is important to highlight that environmental perception is influenced by several factors like individuals' ideology, gender, age, and financial condition. Therefore, each person will show different perceptions about the environment (ASSIS et al., 2020). Environmental perception is also responsible on guiding the educational activities proposed by the EE, showing itself as an important tool when it comes to conservation (PEREIRA et al., 2006). However, EE activities about the marine environment are considerably scarce in the Brazilian coast (BERCHEZ et al., 2005). Additionally, there is a great challenge when we talk about protecting the environment, given the fact that there is a difference between the individuals' values and perceptions about the environment's importance (UNESCO, 1973).

Given the above, this study aimed to give a diagnosis about the Minas Gerais population's knowledge about marine ecosystems and their importance, highlight if there are knowledge gaps on their Environmental Perception and report the importance of Environmental Perception on the field of the marine biology and how it can contribute to conservation and articulate the obtained results with conservation and marine biology.

\section{Theoretical reference}

Several studies such as the one by Ursi et al., (2015) with Biological Sciences' students, it was possible to observe that although they were concerned about marine conservation, it can also be noted that many of them thinks about the marine environment as a resource extraction source. We can also see similar results in the study made by Katon et al., (2013), which was made by questionnaire application at schools. The students associated marine organisms to products manufacturing or also food purposes. With this in mind, we can see that there is such a utilitarian point of view when it comes to the marine environment, so, many people believe that the oceans are just a source of resources or for human activities, such as fishing and sports.

Regarding biodiversity, there are several studies related to animals that hold more aesthetic beauty, as we can see in the studies by Cardoso (2012), Santos (2012) and Monteiro (2005). Consequently, it is noticeable certain 
scarcity of studies about other organisms, and when they occur, people often have problems on identifying the animals (CARDOSO, 2012, FIGUEIRA et al., 2017). It is also noticeable that population frequently have problems on establishing relations with the marine environment (KATON et al., 2013; URSI et al., 2015), or some claim that they have no relationship with the sea, justifying that they live far from the coast. However, this relationship exists even we do not live near coastal areas, since the oceans have a strong ecological role and are capable to influence even distant places (CASTRO; HUBER, 2012; ALBUQUERQUE et al., 2015). Concerning to Environmental Education, its concept and objectives are not very clear to some people, since many say that EE only has the function of providing information, which is not completely wrong, but only providing information is not capable of inducing changes in habits and attitudes (MARCATTO, 2002; URSI et al., 2009; PEDRINI et al., 2012).

When it comes to people's perception about the impacts on marine environment, it is usually notable that they tend to pay much more attention to problems that cause aesthetic problems, since many of them are more concerned about the discomfort that the garbage's presence may cause than about the consequences that this can cause to the marine ecosystems (FILHO et al., 2011). Undoubtedly, aesthetic impacts are a big issue which deserves attention, however, in several studies, people are often unaware about other types of anthropogenic impacts. Only in a few cases some respondents reported bioinvasion, water temperature increases and sediment suspension, but these elements are rarely mentioned (BROTTO et al., 2012; HEISSLER, 2018; KATON, 2015).

\section{Materials and methods}

\section{Questionnaire application}

To carry out the diagnosis, an application of structured scripts was made, which were answered by the public (Most of Minas Gerais) using Google Forms. The script had nine fixed choice questions about marine ecosystems and environmental education's importance. Subsequently, the script ended with two open-ended questions so that the interviewee could freely discuss marine ecosystems in order to complement the fixed choice questions previously answered.

\section{Data analysis}

The fixed choice questions' answers collected were organized in tables using Microsoft Excel and counted using resources provided by the program itself. And for the open-ended questions, the texts were included in a Microsoft Word's file, and they were carefully read in order to divide them into categories, so the qualitative data could be modified to quantitative data. On all data analysis, simple percentage calculus was made. 


\section{Results and discussion}

\section{Respondents' profile}

After completing the application via Google forms, there were a total number of 122 responses, however, 15 were discarded due to the respondents' age being less than 18 years old. It was observed a considerable difference between participants' gender, with 70 being female $(65,4 \%)$ and 37 males $(34,6 \%)$. Between these two groups, it was observed a considerable difference in their scholarly levels from higher education onwards, since most women are attending or have attended higher education. In addition, it is observed that most of the respondents are at least attending higher education, have already completed it, or have a postgraduate degree, suggesting that most of them are well-qualified people. (Figure 1).

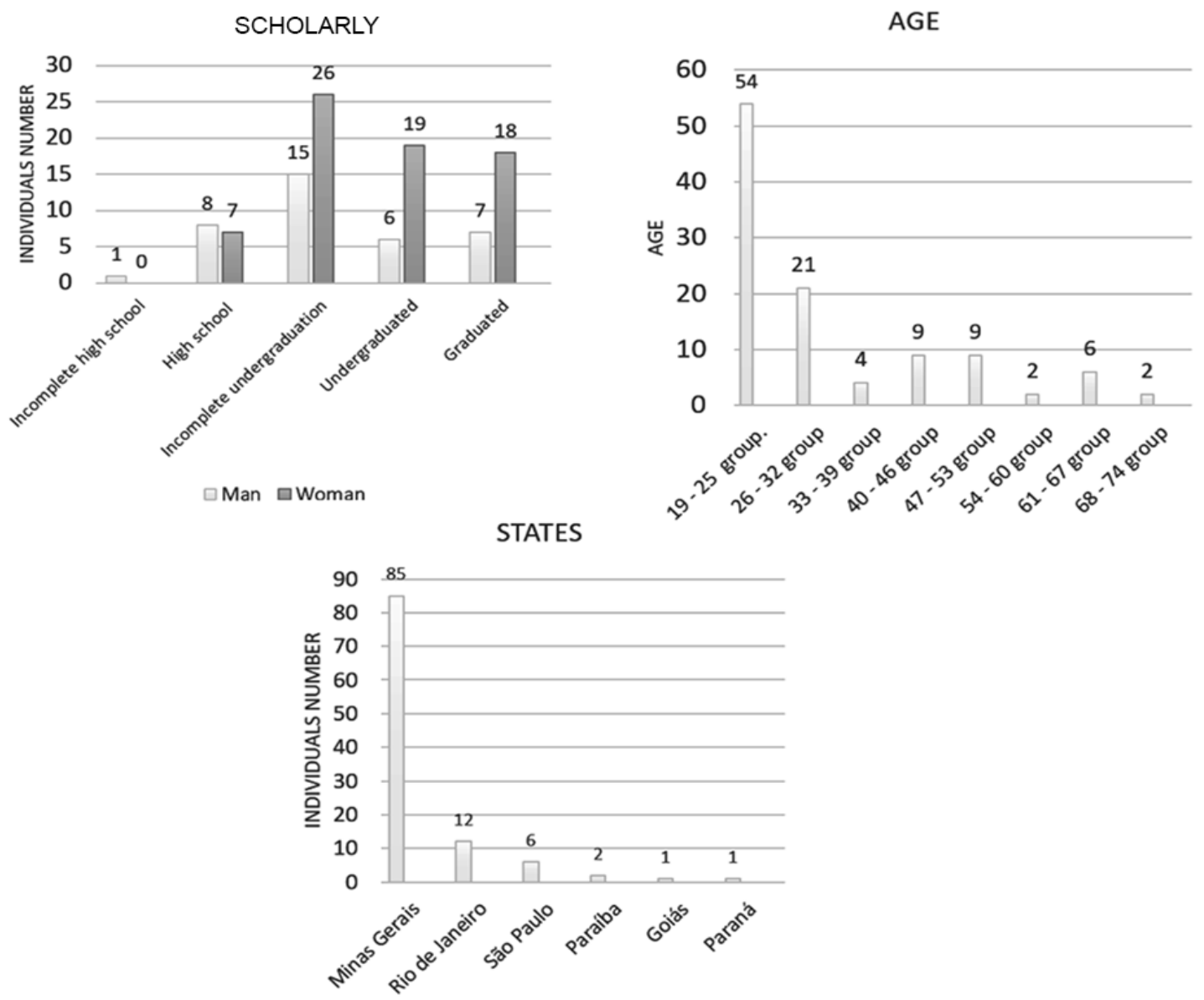

Figure 1: Individuals number according to scholarly level, age and states.

Source: The authors (2021).

The respondents' age varied between 19 to 69 years old, however, a higher frequency was observed between the first two groups: 19 to 25 years old $(50,4 \%)$, and 26 to 32 years old $(19,6 \%)$. Most respondents reside in Minas Gerais state $(79,4 \%)$, but we also have other locations such as Rio de Janeiro $(11,4 \%)$, São Paulo (5,6\%), Paraíba (5,6\%), Paraná $(0,9 \%)$ and Goiás $(0,9 \%)$. 


\section{Marine ecosystems concept}

Most of the interviewees $(73,8 \%)$ showed a proper point of view when it comes to marine ecosystems' concept, therefore, choosing the option that cited living beings and their relations between them and the environment, in addition, the regions that suffer influence from sea waters. However, a significant number of people $(20,6 \%)$ defined marine ecosystems as the present organisms in the sea, thus, excluding landscapes and the regions under the seawater's influence. Only a small portion of the respondents $(5,6 \%)$ excluded the species from this concept, and none of them showed the utilitarian view, in other words, that marine ecosystems are only for man's use, like resources' extraction (Figure 2)

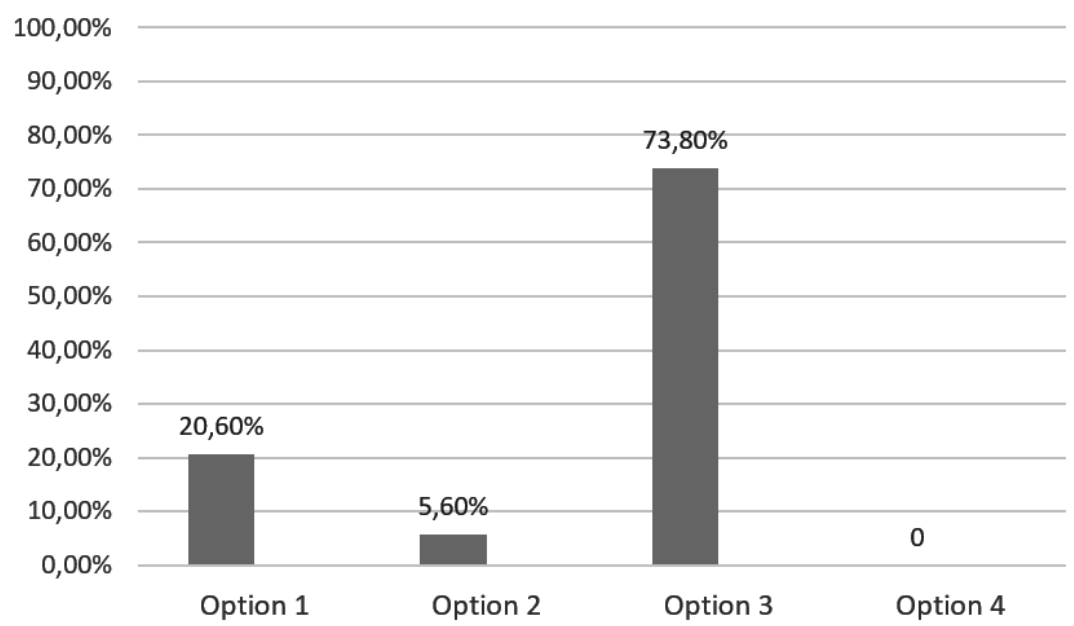

Figure 2: Option's percentage value marked by respondents when they were asked about the concept of marine ecosystems. Option 1: It is the set of animals and living beings present in the marine environment. Option 2: Marine ecosystems are the landscapes and places that encompass the marine environment, regardless of the species. Option 3: They are regions under the seawater's influence and that encompass living beings, their interactions between them and the environment. Option 4: They are coastal areas occupied by man which he uses for his own benefit. Source: The authors (2021).

Even though most of the interviewees had an adequate point of view about this concept, it is noticeable that there are some misconceptions. It is believed that it is due to the fact that marine ecosystems receive little attention in Brazilian territory from the point of view of environmental perception, furthermore, it is worth emphasizing that marine Environmental Education is a recent topic in the country that became more discussed only in the early 2000 s. (BERCHEZ et al., 2005; PEDRINI et al., 2013). Some studies show that an inadequate perception of these environments can put the species at risk, so reinforcing environmental education not only in coastal areas, but also is regions far from the coast, are of extreme importance for marine environments' conservation. (AMARAL; JABLONSKI, 2005). 


\section{Marine Environmental Education's concept}

About the Marine Environmental Education's concept, it was observed that different from the marine ecosystems' concept, part of the interviewees pointed out a utilitarian vision about the topic $(10,5 \%)$, in other words, Marine $\mathrm{EE}$ it is about our comprehension on which ways the man has been using the resources provided by the sea (like food resources, mineral extraction). But this is an inadequate point of view about this topic, considering that EE is about the acquisition of knowledge, skills, and competences collectively aiming to environment's conservation. Although the slight utilitarian tendency was observed, the vast majority of the respondents presented an adequate concept about the theme. $(85,9 \%)$ (Figure 3).

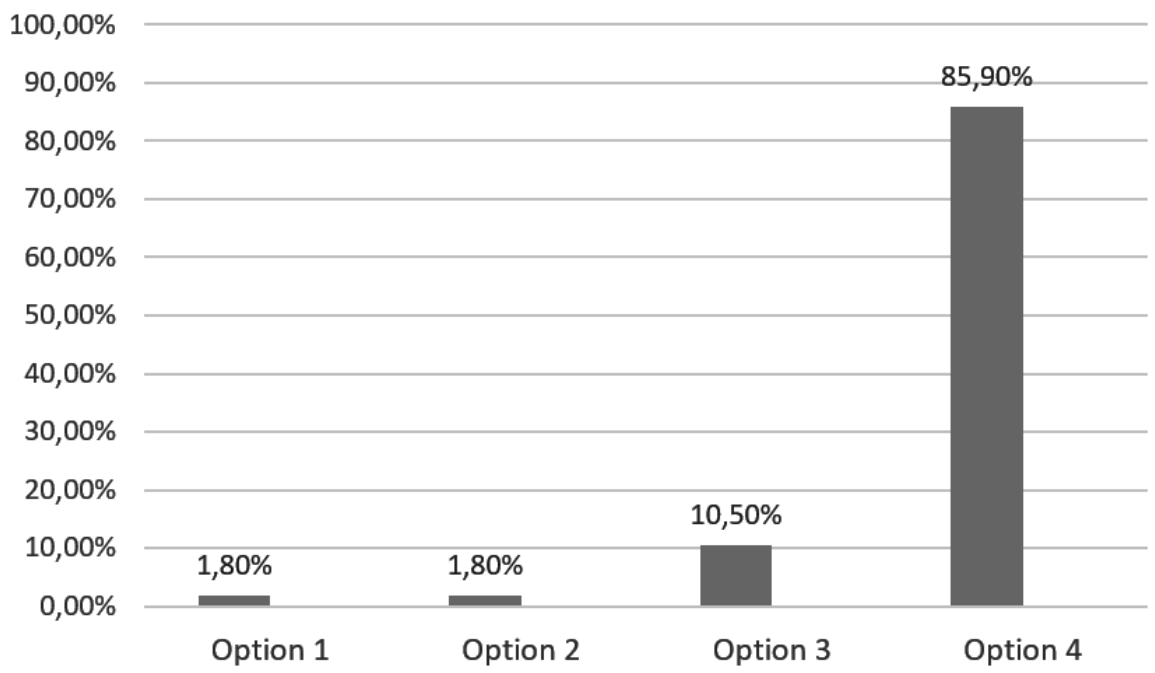

Figure 3 - Percentage value of the options marked by respondents when asked about the concept of marine environmental education. Option 1: It is about acquisition about the marine environment. Option 2: Marine environmental education is what should be taught in schools. Option 3: It is the comprehension about how the human being uses the marine resources, such as food and minerals. Option 4: It is the knowledge's acquisition, skills, values and attitudes aiming the marine environment's conservation.

Source: The authors (2021).

Only a small portion of the individuals defined the theme as only the knowledge's acquisition about marine environment $(1,8 \%)$ and as something that must be taught at schools $(1,8 \%)$. It is important to remember that in the context of EE, the knowledge's acquisition should not be treated in an isolated way, but in conjunction with other factors aiming environmental conservation, so this point of view is partially inadequate. (MARCATTO, 2002). Despite not being an adequate concept, we must emphasize the importance of dealing with this issue in schools, since through Environmental Education is possible to raise awareness among students in order to make them become people concerned about the environment. (NARCIZO, 2009). 


\section{Respondents' perception about the importance and influence of marine ecosystems}

Most of the respondents answered "yes" when asked whether they believe that marine environment had any influence on their lives, and only one of the interviewees believes that marine environment doesn't have any influence on his life, however, there was no justification in the subsequent open-ended questions. About open-ended question number 10, a large number of answers were observed containing elements such as: "Everything in nature is interconnected." or "Everything that happens at sea affects the planet as a whole." Thus, we note that most individuals showed an integrative view about marine environment (Figure 4). According to Reigota (2010), the integrative view is which both natural elements and human-related elements interact and somehow influence each other.

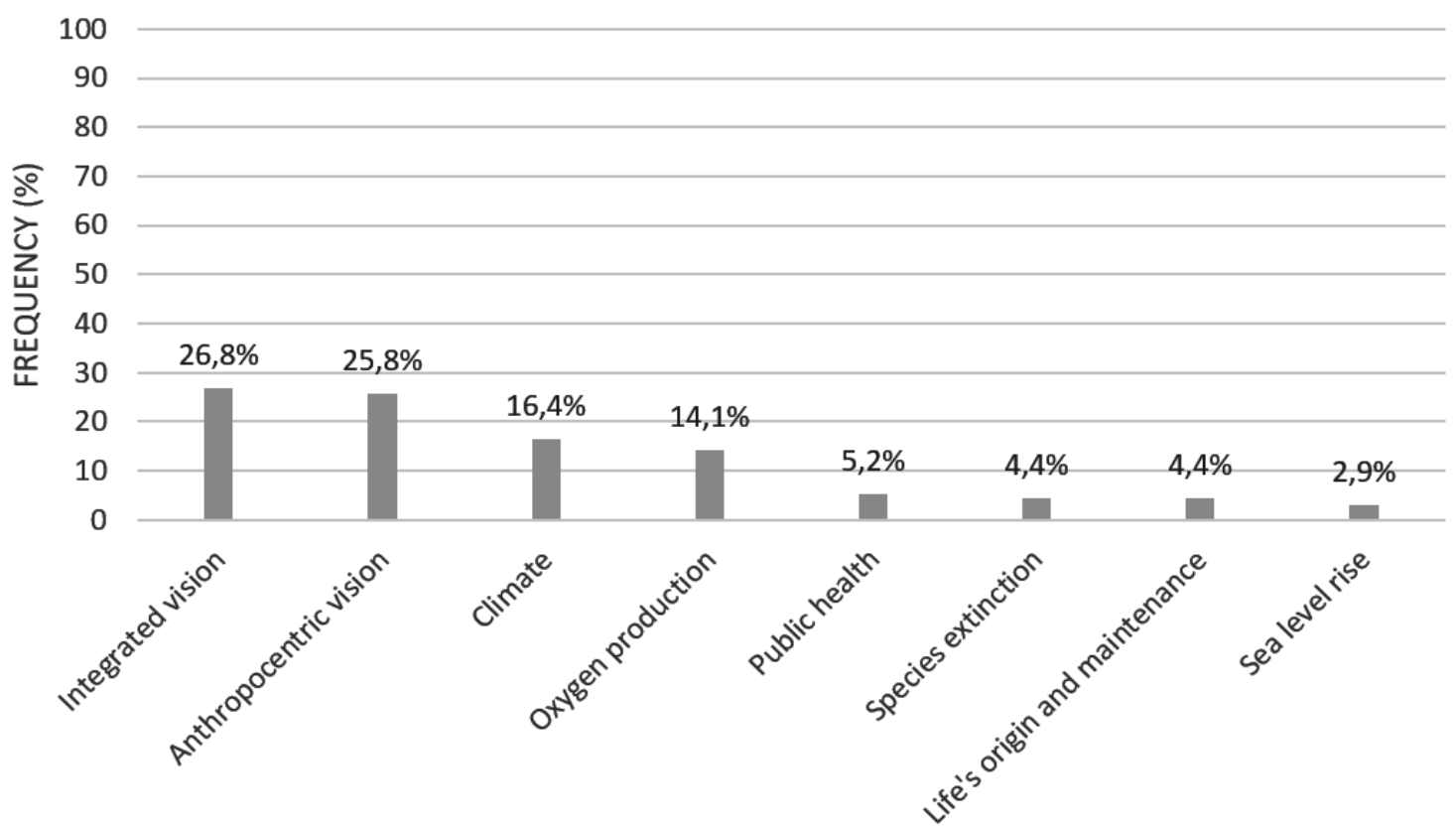

Figure 4: Percentage value of the respondents' most cited elements when asked about the importance and influence that the marine environment has on their daily lives.

Source: The authors (2021).

Following this integrative view, it is noticeable that people commonly tend to have to an anthropocentric point of view about the marine environment, so, they see the oceans only as source of resources extraction or for recreational and touristic purposes (REIGOTA, 2010). It is noticeable that people have certain tendency to have this point of view when it comes to the environment, like evidenced by Pedrini and collaborators (2013), Rosa and Maio (2018) and Albuquerque and collaborators (2015). Climate regulation and oxygen production were frequently mentioned by respondents, $16,4 \%$ and $14,1 \%$ respectively. However, few people cited public health issues, but in some answers were observed involving impacts related to food contamination due to microplastic ingestion by marine animals. 
It was also noted that in some answers, the respondents had problems when establishing relationship with marine ecosystems, justifying with the fact that they live far from the sea, which makes sense, since most of the respondents lives in Minas Gerais state (80\%). These issues are expected since similar results were reported in the studies of Rosa and Maio (2018) and Albuquerque et al. (2015). Furthermore, it is known that in several environmental discussions, marine ecosystems are often omitted, precisely because of their certain distance from everyday life. Thus, it has been made clear the need of Environmental Education actions aiming at making clear to the community that the marine environment plays an important role in our lives even though we are far from coastal areas. (URSI et al., 2009).

\section{Respondents' perception about marine impacts}

Regarding the respondents' perception about the anthropogenic impacts on the marine environment, almost $100 \%$ marked the options related to oil spills and general pollution by solid waste (Figure 5). It is not new that oil spills represent a serious problem for marine ecosystems, considering that incidents with this substance have occurred all around the world, and even in Brazil causing several damages to nature and economy (SZEWCZYK, 2006). However, it is believed that part of the respondents' attention to the issue is due to the oil spill that occurred in September 2019 on the Northeast coast, which caused numerous damages to marine communities and was also responsible for economic losses.

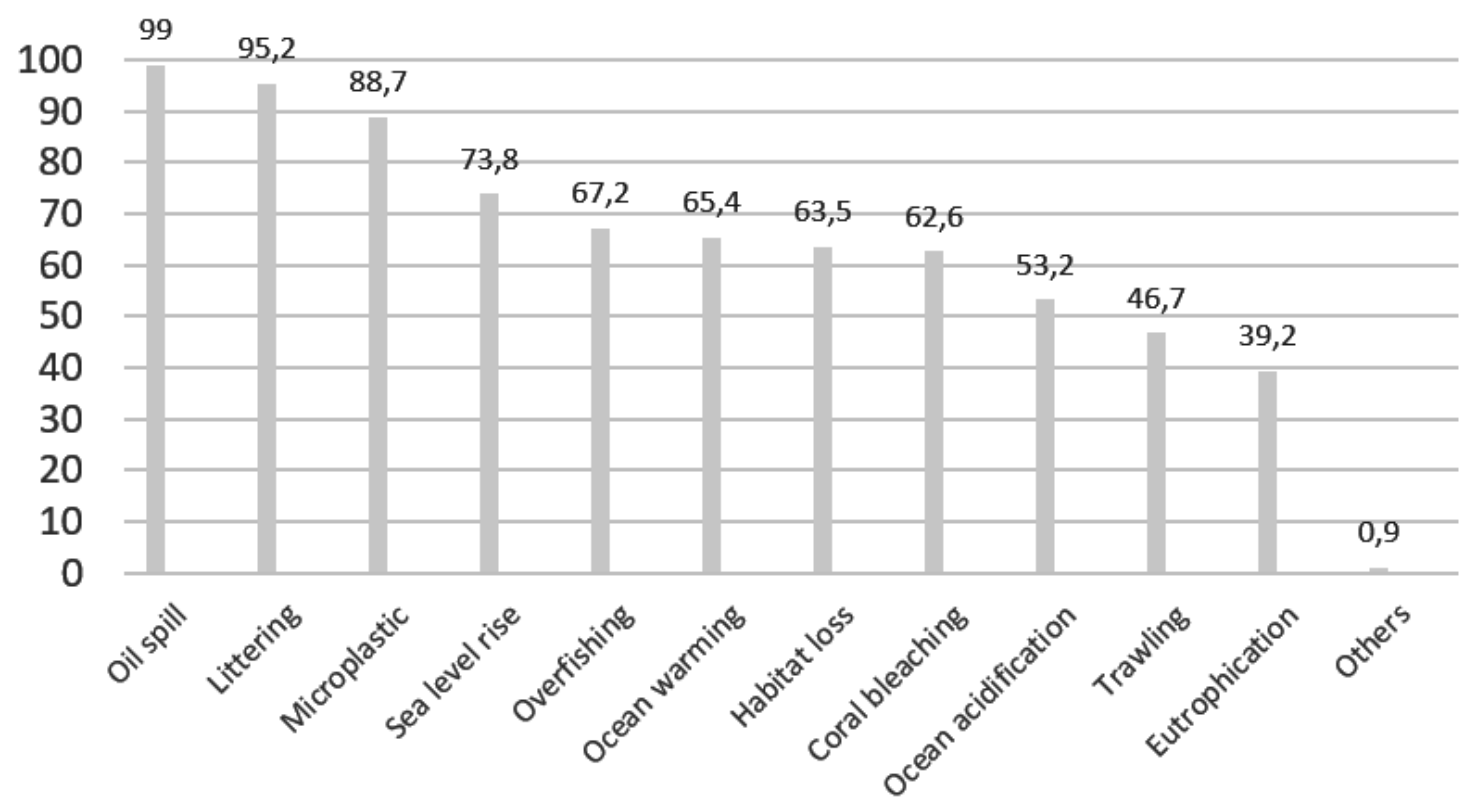

Figure 5: Percentage value of options marked by respondents when asked about which impacts they had any knowledge about.

Source: The authors (2021). 
Respondents also gave a big attention to general pollution by solid waste, and like cited before, people tend to give more attention to impacts that brings aesthetic problems to the environment (FILHO et al., 2011; SANTOS et al., 2005). The same reason can be equally attributed to the attention given to the oil spill issue.

Microplastics were the third most marked option by respondents as shown in the graph (Figure 5), and these results coincide with the open-ended questions, since the vast majority of respondents believe that the impacts caused in the oceans occur mainly due to improper disposal (Table 1). Among the answers, several elements were mentioned, such as microplastic, oil spills, sewage disposal and also residues resulting from capital goods. The population's lack of knowledge and overexploitation of marine resources received the same attention from the interviewees $(25 \%)$, and only a small portion attributed the problems to deforestation close to springs $(6,3 \%)$.

Table 1: Percentage frequency and examples of categories referring to respondents' perception about the main reasons for impacts on the marine environment.

\begin{tabular}{ccl}
\hline Category & Percentage frequency & \multicolumn{1}{c}{ Examples } \\
\hline Improper waste disposal & $43,70 \%$ & $\begin{array}{l}\text { "People do not care about } \\
\text { throwing their garbage into } \\
\text { the ocean." }\end{array}$ \\
\hline Lack of knowledge & $25 \%$ & $\begin{array}{l}\text { "The lack of knowledge and } \\
\text { awareness has caused a lot } \\
\text { of damage to nature..." }\end{array}$ \\
\hline Resources overexploitation & $25 \%$ & $\begin{array}{l}\text { "The overexploitation of } \\
\text { resources, regardless of the } \\
\text { environment where it occurs." }\end{array}$ \\
\hline Deforestation near springs & $6,3 \%$ & $\begin{array}{l}\text { It is still very common to see } \\
\text { many people throwing } \\
\text { garbage in rivers, deforesting } \\
\text { springs and areas close to } \\
\text { rivers and lakes..." }\end{array}$ \\
\hline Total & $\mathbf{1 0 0 \%}$ &
\end{tabular}

It is not incorrect to say that these factors can bring countless problems to marine environment, however, it is worth to remember that all marine impacts are not caused only by a specific action, but by many factors. Among these factors, we can mention the improper disposal of waste or substances (such as sewage or chemicals), to problems related to greenhouse gases into the atmosphere, that brings consequences on marine organisms and consequently for humankind, such as sea level rise, ocean acidification, coral bleaching, habitat loss, eutrophication and others (BOUWER, 2011). However, some of these impacts showed low frequency and were little mentioned by respondents. Only one of them cited problems related to noise pollution generated by maritime traffic. About the anthropogenic actions consequences', most respondents were concerned about species' extinction and disturbance in the food chain (Table 2). These two impacts were mainly associated with 
ecosystem issues and how this could affect marine communities. It is noticeable that in this topic, the interviewees were more concerned about the environment and not only with economic issues.

Table 2: Percentage frequency and examples of categories referring to respondents' perception about how the impacts on the marine environment would bring us consequences.

\begin{tabular}{ccl}
\hline $\begin{array}{c}\text { Category } \\
\text { Species extinction }\end{array}$ & $\begin{array}{c}\text { Percentage frequency } \\
60 \%\end{array}$ & $\begin{array}{l}\text { "There are animals that could } \\
\text { be extinct..." }\end{array}$ \\
\hline Food chain & $20 \%$ & $\begin{array}{l}\text { "Any ecosystem's destruction } \\
\text { could trigger drastic } \\
\text { consequences across the } \\
\text { entire food chain." }\end{array}$ \\
\hline Feeding & $10 \%$ & $\begin{array}{l}\text { "If we throw garbage into the } \\
\text { rivers, they will go to the sea, } \\
\text { which will be contaminated by } \\
\text { objects that can kill the } \\
\text { animals and contaminate } \\
\text { humans whose eat fish and } \\
\text { other food that comes from } \\
\text { the sea." }\end{array}$ \\
& & "..the consequences are \\
& & $\begin{array}{l}\text { more drastic in our climate as } \\
\text { it is already happening." }\end{array}$ \\
\hline Climate & &
\end{tabular}

Source: The authors (2021).

It has been noted that most respondents suggested measures to deal with the impacts caused by human action. The most suggested measures were those related to public interventions, such as habit change, awareness and environmental education proposals (Table 3 ). Only one of the interviewees mentioned the three basic steps in the environmental education process (sensitize, raise awareness and mobilize), however, in other answers the respondents only cited these steps dissociated. The environmental education's processes are of great importance, so we are capable to build a society with environmentally concerned individuals. Nevertheless, it is worthy emphasizing that these three steps must occur one after another, and must not be dissociated, since it is not possible for one to occur without the previous step (SILVEIRA, 2003). 
Table 3: Percentage, frequency and examples of categories referring to the solution proposed by respondents in order to reduce impacts on the marine environment.

\begin{tabular}{|c|c|c|}
\hline Category & Percentage frequency & Examples \\
\hline Habit change & $22 \%$ & $\begin{array}{l}\text { "As long as people do not put } \\
\text { in practice actions for sea's } \\
\text { recovery, we are in serious } \\
\text { danger." }\end{array}$ \\
\hline Awareness & $19,6 \%$ & $\begin{array}{l}\text { "...it is enough that everyone } \\
\text { is aware and respects the } \\
\text { environment as part of } \\
\text { themselves." }\end{array}$ \\
\hline Environmental Education & $16,3 \%$ & $\begin{array}{l}\text { "...with environmental } \\
\text { education, we can use the } \\
\text { resources of these } \\
\text { ecosystems in a sustainable } \\
\text { and non-harmful way." }\end{array}$ \\
\hline Pessimistic point of view & $14,7 \%$ & $\begin{array}{l}\text { "I think there is no way to } \\
\text { revert the impacts caused by } \\
\text { man..." }\end{array}$ \\
\hline Garbage management & $6,5 \%$ & $\begin{array}{l}\text { "...a better planning on the } \\
\text { recycling system so garbage } \\
\text { does not go into these } \\
\text { environments..." }\end{array}$ \\
\hline Mitigation & $6,5 \%$ & $\begin{array}{l}\text { "I believe that with mitigation } \\
\text { it is possible to revert the } \\
\text { situation!" }\end{array}$ \\
\hline Forfeits & $3,2 \%$ & $\begin{array}{l}\text { "The guilty ones must be held } \\
\text { responsible, inspected and } \\
\text { fined..." }\end{array}$ \\
\hline New technologies & $3,2 \%$ & $\begin{array}{l}\text { "I believe that we should use } \\
\text { new technologies on trying to } \\
\text { revert the damage already } \\
\text { caused..." }\end{array}$ \\
\hline Public policy & $3,2 \%$ & $\begin{array}{l}\text { "Human being is capable of } \\
\text { reverting the impacts, but } \\
\text { there is a need of behavior } \\
\text { change, political change and } \\
\text { protected areas expansion... }\end{array}$ \\
\hline Research & $3,2 \%$ & $\begin{array}{l}\text { "The human being is capable } \\
\text { to revert this situation through } \\
\text { research and development... }\end{array}$ \\
\hline Divulgation & $1,6 \%$ & $\begin{array}{l}\text { " I wish that more public } \\
\text { channels like social media, } \\
\text { television and magazines } \\
\text { spoke more about how to } \\
\text { protect marine life.." }\end{array}$ \\
\hline
\end{tabular}

Source: The authors (2021).

A significant number of respondents presented a pessimistic point of view when it comes to human impacts. Many justified this thought saying that it is no longer possible to revert the caused damage, but some presented a less 
pessimistic point of view, claiming that we can mitigate the impacts previously caused. Mitigation measures, forfeits and public policies were also suggested. Such measures are indispensable in marine and terrestrial ecosystems' conservation. However, it is vital that these actions come from different society's spheres (FERNANDES; SANSOLO, 2013). Elements like inspection and forfeits were in several answers, however, despite their great importance, these measures are not always effective, and they need to be allied to environmental education (MMA, 2010).

\section{Conclusion}

More than a half of respondents were female, including individuals mostly between 19 and 32 years old. Most of the interviewees had high education levels, and most of them are still studying or have attended to higher education. Although most of them resides far from the coast (In the majority being from Minas Gerais state), it is remarkable that they showed adequate conceptions regarding marine ecosystems, marine environmental education, and did not show difficulty on assigning importance and establishing relationships with the sea, also associating it with climate regulation and oxygen production. Only a small portion presented inadequate conceptions regarding these topics, and we believe that this has relation with respondents' high education levels.

The integrative point of view about the environment was the most prevalent, however, the anthropocentric view about the marine environment showed high frequency in the answers, like it was reported in other studies. About the impacts, there was a higher frequency of answers involving general pollution, such as solid waste, oil spills and microplastic. Factors related to climate change received less attention, and like it was evidenced in other studies, this is since pollution by solid or chemical waste often brings damage to environment's natural beauty, which usually draws more public attention (BROTTO et al., 2012). However, unlike in other studies, some respondents were also concerned about environmental issues and not only because they feel uncomfortable with pollutants' presence.

Habit change, environmental education and awareness were the most suggested solutions in order to reduce human impacts on the marine environment. However, a significant number of respondents do not have a good point of view about these issues, believing that the marine impacts are irreversible. Measures not involving the public were rarely mentioned. Also, it is known that the general public and especially the local communities are vital when it comes to environmental conservation, thus, environmental education interventions are of great importance for the community to understand their context in which they are inserted in order to guide properly decision-making by public authorities. But it is worth to remember that actions aiming environmental conservation must come from various spheres of society, because we are all dependent on the marine environment. 
Acknowledgments: To Pontifical Catholic University of Minas Gerais and PUC Minas' Research Ethics Committee for making this study possible. We also would like to thank the interviewees for agreeing to participate in this survey and to Priscila Veliq for helping on writing the English version.

\section{Referencies}

ALBUQUERQUE, R.M.V.L.; FARIAS, E.M.N.; MAIA, R.C. Educação ambiental para o ecossistema manguezal: $O$ papel dos pescadores artesanais. Conex. Ci. e Tecnol. Fortaleza/CE, v. 9, n. 3, p. 41 - 50, nov. 2015.

AMARAL, A.C.Z.; JABLONSKI, S. Conservação da biodiversidade marinha e costeira no Brasil. Megadiversidade, v. 1, n. 1, 2005.

ASSIS, D.M.S.; TAVARES-MARTINS, A.C.C.; BELTRÃO, N.E.S.; SARMENTO, P.S.M. Percepção ambiental em comunidades tradicionais: um estudo na Reserva Extrativista Marinha de Soure, Pará, Brasil. Ambiente \& Sociedade, v. 23, 2020.

BARROS-PLATIAU, A.F.; BARROS, J.G.C.; MAZZEGA, P.; OLIVEIRA, L.P.S. Correndo para o mar no antropoceno: a complexidade da governança dos oceanos e a estratégia brasileira de gestão dos recursos marinhos. Revista de Direito Internacional, v. 12, n. 1, p. 149-168, 2015.

BERCHEZ, F. A. S.; CARVALHAL, F.; ROBIM, M. J. Underwater interpretative trail: guidance to improve education and decrease ecological damage. Int. J. Environment and Sustainable Development, Nairobi, v. 4, n. 2, p. 128-139. 2005.

BERCHEZ, F.; GHILARDI, N.; ROBIM, M.J.; PEDRINO, A.G.; HADEL, V.F.; FLUCKIGER, G.; SIMÔES, M.; MAZZARO, R.; KLAUSENER, C.; SANCHES, C.; BESPALEC, P. Projeto trilha subaquática: Sugestão de diretrizes para a criação de modelos de Educação Ambiental em Unidades de Conservação ligadas a ecossistemas marinhos. OLAM Ciência \& Tecnologia, Rio Claro/SP, Brasil Ano VII, v.7.no 3 Pag. 181. Dezembro de 2007.

BOUWER, L.M. Have disaster losses increased due to anthropogenic climate change? Bulletin of the American Meteorological Society, v. 92, p. 39-46,

BRASIL, Política Nacional de Educação Ambiental - Lei ㄲo 9795/1999, Art 1ํ. Disponível em: <https://www.mma.gov.br/educacao-ambiental/pol\%C3\%ADticanacional-de-educa\%C3\%A7\%C3\%A30-ambiental.html>. Acesso em: 14 out. 2019.

BROTTO, D.S.; PEDRINI, A.G.; BANDEIRA, R.R.C.; ZEE, D.M.W. Percepção ambiental do mergulhador recreativo no Município do Rio de Janeiro e adjacências: subsídios para a sustentabilidade do ecoturismo marinho. Revista Brasileira de Ecoturismo, São Paulo, v.5, n.2, p. 297-314, maio / agosto 2012.

CALDAS, A.H.M. Análise da disposição de resíduos sólidos e da percepção dos usuários em áreas costeiras - Um potencial de degradação ambiental. Monografia (Curso de pós-graduação em Gerenciamento e Tecnologia Ambiental no Processo Produtivo). Escola Politécnica, Universidade Federal da Bahia, Salvador, 2007. 
CAMPOS, M.L.A.M.; JARDIM, W.F. Aspectos relevantes da biogeoquímica da hidrosfera. Cadernos Temáticos de Química Nova na Escola, ${ }^{\circ} 5$, novembro de 2003.

CARDOSO, C.C. Percepção de estudantes que visitam o Projeto TAMAR - ICMBio, nas bases de Florianópolis - SC e Ubatuba - SP, sobre biologia e conservação de tartarugas marinhas. Dissertação (Curso de especialização em diversidade e conservação da Fauna) - Universidade Federal do Rio Grande do Sul, Porto Alegre, 2012.

CASTRO, P.; HUBER, M.E. Biologia Marinha. 8.ed. AMGH Editora Ltda, 2012.

FALASCHI, R.L.; CAPELLARI, R.S.; OLIVEIRA, S.S. Museus de ciência: do reconhecimento e conservação da biodiversidade à divulgação científica. Revista Simbio-Logias, v. 4, n. 6, p. 12-23, 2011.

FELÍCIO, R.; OLIVEIRA, A.L.L.; DEBONSI, H.M. Bioprospecção a partir dos oceanos: conectando a descoberta de novos fármacos aos produtos naturais marinhos. Ciência e Cultura, v. 64, n. 3, p. 39-42, 2012.

FERNANDES, I.G.; GOMES, A.A.; LAPORTA, J.L. Educação Ambiental marinha na reserva de desenvolvimento sustentável Barra do Una, Peruíbe (SP). Revista Brasileira de Educação Ambiental, São Paulo, v. 12, no 1: 177-194, 2017.

FERNANDES, L.G.; SANSOLO, D.G. Percepção ambiental dos moradores da cidade de São Vicente sobre os resíduos sólidos na Praia do Gonzaguinha, SP, Brasil. Revista de Gestão Costeira Integrada - Journal of Integrated Coastal Zone Management, v. 13, №. 3, p. 379-389, 2013.

FIGUEIRA, S.G.S.; CORREIA, M.D.; SOVIERZOSKI, H.H. Percepção do ambiente marinho com base em mapas mentais por alunos do interior de Alagoas. Experiências em Ensino de Ciências, v.12, nํ․, 2017.

FILHO, M.D.; SILVA-CAVALCANTI, J.S.; ARAUJO, M.C.B.; SILVA, A.C.M. Avaliação da Percepção Pública na Contaminação por Lixo Marinho de acordo com o Perfil do Usuário: Estudo de Caso em uma Praia Urbana no Nordeste do Brasil. Revista de Gestão Costeira Integrada. V.11, n‥1, p.49-55, 2011.

GODOI, A.F.L.; FAVORETA, R.; SANTIAGO-SILVA, M. Contaminação ambiental por compostos organoestânicos. Quim. Nova, v. 26, nํ. 5, 708-716, 2003.

GRASSI, M.T. As águas do planeta Terra. Química Nova na Escola, Cadernos Temáticos, v.1, pp.31-40, 2001.

HEISSLER, V.L. Ecossistemas marinhos e costeiros do Rio Grande do Sul: O que sabem os estudantes de ensino médio? Monografia (Curso de Licenciatura em Ciências Biológicas) - Universidade Federal do Rio Grande do Sul - UFRGS, Porto Alegre, 2018.

KATON, G.F. Percepção Ambiental de professores em ecossistemas costeiros: influência de uma vivência formativa do Projeto Trilha Subaquática. Dissertação (Mestrado em Ciências Biológicas na área de botânica) - Universidade de São Paulo, São Paulo, 2015. 
KATON, G.F.; TOWATA, N.; BERCHEZ, F.A.S. Percepção de estudantes que vivem distantes do litoral sobre o ambiente marinho. Anais do IX Congresso internacional sobre investigação na didática das ciências, 2013.

MARCATTO, C. Educação ambiental: Conceitos e princípios. 1.ed. Belo Horizonte: FEAM, 2002.

MINISTÉRIO DO MEIO AMBIENTE. Panorama da Conservação dos Ecossistemas Costeiros e Marinhos no Brasil. Brasília: Secretaria de Biodiversidade, p. 148, 2010.

MONTEIRO, A.F.; ESTIMA, S.C.; MONTEIRO, D.S.; GANDRA, T.B.R. Educação ambiental e envolvimento comunitário: Ações desenvolvidas pelo Projeto Tartarugas Marinhas - NEMA. Anais da II Jornada de Conservação e Pesquisa de Tartarugas Marinhas no Atlântico Sul Ocidental, Praia do Cassino, novembro de 2005.

NARCIZO, K.R.S. Uma análise sobre a importância de trabalhar educação ambiental nas escolas. Revista Eletrônica do Mestrado em Educação Ambiental, v. 22, 2009.

PEDRINI, A.G.; BROTTO, D.S.; LOPES, M.C.; FERREIRA, L.P.; GHILARDI-LOPES, N.P. Percepção sobre meio ambiente e o mar por interessados em ecoturismo marinho na área de proteção ambiental marinha de armação de Búzios, Estados do Rio de Janeiro, RJ, Brasil. Pesquisa em Educação Ambiental, v. 8, no․ 2, pp 59-75, 2013.

PEDRINI, A.G.; BROTTO, D.S.; MESSAS, T.P. Avaliação de aproveitamento no I Curso de Atualização em EA para o turismo marinho e costeiro (I CEAM). Revista Eletrônica do Mestrado em Educação Ambiental, v. 28, janeiro a junho de 2012.

PEDRINI, A.; COSTA, E.A.; GHILARDI, N. Socially vulnerable children and preadolescents environmental perceptions in education projects. Ciência \& Educação, v. 16, №. 1, p. 163-179, 2010.

PEDRINI, A.G.; MESSAS, T.P.; PEREIRA, E.S.; GHILARDI-LOPES, N.P.; BERCHEZ, F.A. Educação Ambiental pelo Ecoturismo numa trilha marinha no Parque Estadual da Ilha Anchieta, Ubatuba (SP). Revista Brasileira de Ecoturismo, São Paulo, v.3, no.3, 2010, pp.428-459.

PEREIRA, E.M.; FARRAPEIRA, C.M.R.; PINTO, S.L. Percepção e Educação Ambiental sobre manguezais em escolas públicas da região metropolitana do Recife. Revista Eletrônica do Mestrado em Educação Ambiental, v.17, julho a dezembro de 2006.

REIGOTA, M.A.S. Meio ambiente e representação social. 8. ed. São Paulo: Cortez, 93p, 2010.

ROSA, P.S.; MAIO, A.C.D. A importância do trabalho de campo para a Educação Ambiental: experiência realizada com alunos do ensino médio no ecossistema manguezal. Revista Eletrônica do Mestrado em Educação Ambiental. Rio Grande, v. $35, n^{\circ} .1$, p. 21-41, jan./abr. 2018.

SANTOS, A.E.M. Educação Ambiental para conservação de tartarugas marinhas. Trabalho de Conclusão de Curso (Curso de Ciências Biológicas) - Universidade do Vale do Paraíba, São José dos Campos, São Paulo, 2012. 
SANTOS, I.R.; FRIEDRICH, A.C.; WALLNER-KERSANACH, M.; FILLMANN, G. Influence of socio-economic characteristics of beach users on litter generation. Ocean \& Coastal Management, v. 48, №. 9-10, p. 742-752, 2005.

SILVA, A.G.S.; RODRIGUES, C.S.L.; ARAúJO, R.R.L. Projeto Calypso: Educação ambiental no complexo estuarino-lagunar Mundaú-Manguaba, Alagoas. Boletim de Estudos de Ciências do Mar, Maceió, no. 12, p. 99-111, 2002.

SILVEIRA, G.T.R. Educação ambiental como instrumento de gestão de recursos hídricos: uma proposta de intervenção. Anais... IX Congresso da Associação Brasileira de Estudos do Quaternário. II Congresso do Quaternário de Países de Línguas Ibéricas. II Congresso sobre Planejamento e Gestão da Zona Costeira dos Países de Expressão Portuguesa. 2003.

SOUZA, K.G.; MARTINS, L.R.S.; CAVALCANTI, V.M.M.; PEREIRA, C.V.; BORGES, L. Recursos minerais marinhos: fatos portadores de futuro, prioridades de estudo no Brasil e projetos estruturantes. Parcerias estratégicas, v.12, no.24, p.247-262, 2010.

SZEWCZYK, S.B.O. Processos envolvidos em um derramamento de óleo no mar. Anais do Seminário e Workshop em Engenharia Oceânica (SEMENGO). 2006.

TOWATA, N.; KATON, G.F.; BERCHEZ, F.A.S.; URSI, S. Ambiente marinho, sua preservação e relação com o cotidiano: Influência de uma exposição interativa sobre as concepções de estudantes do ensino fundamental. Anais do IX Congresso internacional sobre investigação na didática de ciências, setembro de 2013.

UNESCO. Man and the Biosphere Programme (MAB). Expert Panel of Project 13: Perception of Environmental Quality. Paris/França, mar. 1973. Disponível em: $<$ http://unesdoc.unesco.org/images/0000/000032/003216eb.pdf>. Acesso em $14 \mathrm{de}$ outubro de 2019.

UNESCO, Sociedade é convocada a construir diretrizes para a Década do Oceano no Brasil. Disponível em: <https://pt.unesco.org/news/sociedade-econvocada-construir-diretrizes-decada-do-oceano-no-brasil> Acesso em: 31 de maio de 2021.

URSI, S.; TOWATA, N.; BERCHEZ, F.A.S.; GHIRADI-LOPES, N.P. Concepções sobre Educação Ambiental em curso de formação para educadores do projeto ecossistemas costeiros (Instituto de Biociências - USP). Anais do Encontro Nacional de Pesquisa em Educação em Ciências, Florianópolis, novembro de 2009.

URSI, S.; TOWATA, N.; SAITO, L.C. Análise da Percepção Ambiental sobre ecossistemas marinhos e costeiros de licenciandos ingressantes em programa de formação docente. Anais do IX Congresso internacional sobre investigação na didática das ciências, novembro de 2015. 